\title{
Energy Retention, Energy Expenditure, and Growth in Healthy Immature Infants
}

\author{
O. G. BROOKE, ${ }^{(38)}$ J. ALVEAR, AND M. ARNOLD \\ Pediatric Department, St. Mary's Hospital, London, and Department of Child Health, St. George's Hospital, London
}

\begin{abstract}
Summary
Energy balance studies were done during 10-29 days on 15 immature infants of mean birth weight $1581 \mathrm{~g}$. Mean gross energy intake was $757 \mathrm{~kJ} / \mathrm{kg}(181 \mathrm{kcal})$ and $79 \%$ of this was retained, so that metabolizable energy was $602 \mathrm{~kJ} / \mathrm{kg}(143 \mathrm{kcal})$. Mean resting metabolic rate was $244 \mathrm{~kJ} / \mathrm{kg}(58.1 \mathrm{kcal})$, and it increased with advancing maturity. Minimum resting metabolism averaged 199 $\mathrm{kJ} / \mathrm{kg}$ (47.5 kcal). Energy expended in activity increased with maturity, but amounted to less than $17 \%$ of the total energy turnover. Postprandial metabolism caused the mean $\mathrm{VO}_{2}$ to rise by $17 \%$ in the hour after a feed, and during $24 \mathrm{hr}$ resulted in consumption of energy equivalent to about $10 \%$ of the resting metabolism. Stored energy amounted to $230 \mathrm{~kJ} / \mathrm{kg}(55 \mathrm{kcal})$ and was linearly related to weight gain $(r=0.92)$. Energy cost of weight gain was $24 \mathrm{~kJ} / \mathrm{g}(5.7 \mathrm{kcal})$ and energy stored in new tissue was $16.8 \mathrm{~kJ} / \mathrm{g}(4.0 \mathrm{kcal})$. Maintenance energy requirement at zero growth rate was about $270 \mathrm{~kJ} / \mathrm{kg}(64 \mathrm{kcal})$.
\end{abstract}

\section{Speculation}

Data on energy balance in immature infants are scanty. There is need for information on energy retention, maintenance energy requirements, postprandial energy expenditure, and energy cost of growth. We have attempted to provide such information, but our data show wide variation between infants. However, in spite of this variation, a clear relationship is present between energy retention and weight gain, the main limiting factor in weight gain probably being energy absorption from the gut. We need more data to show whether efficiency of energy utilization alters with different levels of intake and at different ages.

Although we now know a great deal about the energy cost of growth in infants recovering from malnutrition (25), we know surprisingly little about it in well nourished infants. This is true even of healthy immature infants (whose growth rates are similar to those of recovering malnourished babies), despite a wealth of available data on almost every other aspect of their metabolism. Immature infants are usually nourished with some form of modified cow's milk, so we have investigated energy retention, heat production, and growth rates in a group of premature babies fed exclusively on one such formula, representative of the present generation of low solute commercial milks.

\section{MATERIALS AND METHODS}

\section{INFANTS}

Fifteen immature infants were studied. They were all above the third weight centile at birth and we did not consider any of them to be undernourished on the basis of weight:length ratios. Birth weights ranged from $990-2030 \mathrm{~g}$ (mean $1581 \mathrm{~g}$ ) and gestation from 29-35 weeks, confirmed by the Dubowitz assessment (7) in case of doubt. Details are given in Table 1. We did not study any infants who persistently vomited more than trivial amounts. Four infants developed transient late metabolic acidosis (14) during the course of the studies. This interfered with energy retention and weight gain (4), but since the infants remained active and apparently well, these results have been included, inasmuch as they enabled us to examine energy balance during periods of poor weight gain.

\section{FEEDING}

All the infants were fed on V Formula (Cow and Gate Baby Foods Ltd., Trowbridge, England). No studies were undertaken until a daily feed intake of $180 \mathrm{ml} / \mathrm{kg}$ or more had been achieved, which was usually by the middle of the second week of life. Mean feed intake during study periods was $227 \mathrm{ml} / \mathrm{kg}$ (range 198-262). The feeds were given 2-3 hourly depending on the size of the infants.

\section{FEED COMPOSITION}

$\mathrm{V}$ Formula is a filled milk prepared from skimmed milk, lactose and vegetable oils, with the following composition (per $100 \mathrm{ml}$ prepared feed): fat, $3.1 \mathrm{~g}$; protein, $1.8 \mathrm{~g}$; CHO (lactose), $7.0 \mathrm{~g}$; mineral salts $0.4 \mathrm{~g}\left(\mathrm{Na}, 26 \mathrm{mg} ; \mathrm{K}, 61 \mathrm{mg} ; \mathrm{Ca}, 62 \mathrm{mg} ; \mathrm{PO}_{4}, 50 \mathrm{mg}\right)$ energy $260 \mathrm{~kJ}(62 \mathrm{kcal})$. The gross energy, determined by us by bomb calorimetry (20) on 23 separate occasions was $344 \mathrm{~kJ} / 100$ $\mathrm{ml}$ (SD 14), $32 \%$ more than the specified energy, the value for which is derived from theoretical considerations as "metabolizable energy" (32).

\section{ASSESSMENT OF GROWTH}

A number of anthropometric measurements were made during the course of the studies:

Weight was measured daily on a Marsden beam balance to the nearest $5 \mathrm{~g}$.

Crown-Heel Length was measured weekly (28) to the next succeeding $1.0 \mathrm{~mm}$ on a neonatal stadiometer.

Occipito-Frontal Head Circumference was measured weekly to the next succeeding $1.0 \mathrm{~mm}$ with fibreglass tape.

In nine infants we also measured:

Triceps and Subscapular Skinfolds (27) to the next succeeding $0.1 \mathrm{~mm}$ with a Harpenden caliper (Holtain Ltd., Crymmych, Pembrokeshire, G.B.), the readings being taken after the jaws had ceased contracting on the fold (usually about $30 \mathrm{sec}$ ). Measurements were made twice weekly.

Elbow-Wrist and Knee-Heel Length to the next succeeding 1.0 mm using a small stadiometer specially designed for the purpose (we have found these linear measurements to be more reproducible than crown-heel or crown-rump length). These measurements were made weekly.

Growth rates were calculated by the method of least squares.

\section{DETERMINATION OF ENERGY RETENTION}

Balances were made over 10 day periods in all infants. When the length of hospital stay allowed, they were repeated after an 
Table 1. Clinical details of 15 immature infants

\begin{tabular}{llclc}
\hline & Sex & BW (kg) & $\begin{array}{c}\text { Birth } \\
\text { length } \\
\text { (cm) }\end{array}$ & $\begin{array}{c}\text { Gestation } \\
\text { (wk) }\end{array}$ \\
\hline 1. G. A. & F & 990 & 37 & 29 \\
2. H. S. & M & 1770 & 41.5 & 31 \\
3. P. R. & F & 1150 & 40.5 & 30 \\
4. P. H. & F & 1685 & 42 & 32 \\
5. J. A. & M & 1490 & 44 & 33 \\
6. T. F. & M & 1410 & 42 & 32 \\
7. J. S. & M & 1350 & 42.5 & 32 \\
8. Y. K. & F & 1070 & 39 & 30 \\
9. S. I. & F & 1630 & 42 & 32 \\
10. R. W. & M & 1865 & 43 & 32 \\
11. S. B. & F & 1750 & 43.5 & 33 \\
12. P. H. & M & 1920 & 46 & 34 \\
13. G. B. & F & 2030 & 46 & 35 \\
14. A. W. & F & 1710 & 42 & 33 \\
15. M. M. & F & 1895 & 44.5 & 34 \\
Mean & & & & \\
\hline
\end{tabular}

interval, and, in some infants, three balances were achieved. Mean age at onset of the initial balance was 14 days (range 8-18 days); at the onset of the second balance (nine infants), it was 27 days (23-34 days); and at the onset of the third balance (three infants), it was 42 days (39-43 days). During these periods, the average weight of the infants was $1.54,1.92$, and $2.31 \mathrm{~kg}$, and their maturity 35,37 , and $39 \mathrm{wks}$, respectively.

\section{INTAKE}

Feed volumes were measured by syringe. Unconsumed energy was minimized by washing the residues in the containers with small amounts of distilled water and giving the baby the washings. Most feeds were given by naso-gastric tube. When bottle feeds were used, dribbles were collected on weighed towelling and their volume determined by weight for subtraction from the measured intake. The infants were nursed in their cots or incubators with weighed absorbant napkins under their heads. Small vomits and regurgitations were collected on these and deep frozen for later analysis.

\section{EXCRETORY LOSSES}

Stools and urine were collected in close fitting preweighed plastic-backed wood pulp napkins. Urine leakage was prevented by ensuring a good fit around the infant's thighs and waist. For convenience of handling, stools were grossly separated from the urine within the napkin with a rayon liner. At each napkin change, all traces of stools were removed from the infant's buttocks with the edges of the liner, and the stools and soiled napkins were promptly placed in sealed polythene bags and frozen at $-24^{\circ}$ while awaiting analysis. Onset and termination of balance periods was marked with carmine. Excreta were aggregated in $24 \mathrm{hr}$ periods. The stools were scraped from the liners into containers and either oven dried at $105^{\circ}$ to constant weight or freeze dried. The soiled liners and the napkins for each 24 -hr period, together with any vomits collected during the same day, were reweighed and then soaked in a known volume of water at $0^{\circ}$ overnight. After thorough pulping and stirring, aliquots were removed for drying and determination of energy in the residue. Total daily energy excretion in the napkins was calculated from the known dilutions.

\section{DETERMINATION OF ENERGY IN EXCRETA}

The energy content of the excreta was determined in triplicate by bomb-calorimetry (20), using benzoic acid as the energy standard.

Energy retention per day was calculated as the difference between energy intake and energy losses in stools, urine, and vomit.

\section{MEASUREMENT OF ENERGY EXPENDITURE}

Multiple measurements of oxygen consumption $\left(\dot{\mathrm{VO}}_{2}\right)$ and carbon dioxide excretion (from which were determined the respiratory quotient (RQ) and the metabolic rate (MR)), were made before, during, and after feeds, and during sleep and wakefulness throughout the balance periods. The measurements were made by open circuit indirect calorimetry with a Kipp Noyens Diaferometer (Kipp \& Zonen, Delft, Holland), which measures the $\mathrm{O}_{2}$ and $\mathrm{CO}_{2}$ concentrations in expired air by thermal conductivity (6).

During determinations the infant was placed either in an acrylic head box or in a larger chamber containing the whole infant. The infant was clothed during the investigations, which were made at room temperature. The head box was clamped with an airtight seal to a padded base on which the infant's head lay. Air was drawn past his face at 1.6 or 4.0 liter/min by the calibrated pump in the diaferometer, entering the box around his neck and leaving through an outlet at the rear, connected to the diaferometer with rubber hose. Care was taken to prevent expired air escaping around the infant's neck by loosely filling the gap with cotton wool. This also served to diffuse the incoming air current and to minimize disturbance of the infant once he had settled down.

In some studies, the infants were placed in an acrylic metabolic chamber, which allowed free movement. This had an opening side panel sealed with an " $O$ " ring by quick release catches, and was otherwise airtight, save for an inlet vent near the infant's feet and an outlet port behind his head, which was connected to the diaferometer.

Each metabolic rate determination was made over a 5-10 min period. The technique of pre- and postprandial measurements has already been described (5). The diaferometer was calibrated using pure $\mathrm{O}_{2}$ and $\mathrm{CO}_{2}$ delivered at known flow rates, and by burning alcohol for regular checks of $\mathrm{RQ}$.

\section{THERMAL ENVIRONMENT}

Infants under $1800 \mathrm{~g}$ were nursed in a hot nursery at $31-33^{\circ}$ ambient temperature, away from external windows. Larger infants were kept in an intermediate nursery where the temperature was $25-27^{\circ}$. When incubator nursing was considered necessary, incubator temperatures were adjusted according to the infant's skin temperature, Hey's charts being used for general guidance (11). During metabolic rate determinations, rectal and abdominal skin temperatures were measured using a Light Laboratories 4-channel thermistor thermometer with purpose-made infant skin and rectal probes. If rectal temperature was below $36.5^{\circ}$ or abdominal temperature below $35.5^{\circ}$, the infant was considered to be under thermal stress and the study was postponed.

\section{ACTIVITY}

We had no reliable way to assess overall energy expenditure due to activity in immature infants over prolonged periods. By measuring metabolic rate during sleep, quiet wakefulness, and active wakefulness, and by documenting, through nursing observations, the proportion of time spent from day to day in these states on certain days during the study periods, we arrived at an estimate of energy spent in activity. Activity observations were made over three separate periods of $1 \mathrm{hr}$ during 1 day in each study period, the observation periods being in the morning, in the afternoon, and between 1.00 and $4.00 \mathrm{hr}$ at night. These observation periods were timed to include a preprandial hour, a postprandial hour and an intermediate hour, in the majority of the infants who were on three-hourly feeding. The observing nurse recorded time spent in five different defined levels of activity: 1) sleeping; 2) awake with occasional movements; 3 ) awake with active movements; 4) awake with active movements and propulsion around the incubator; 5) crying. She used her judgement in assigning intermediate levels of activity to the category above or below it on the scale. We did not differentiate between different sleep states because it has been shown that they do not have an important effect on oxygen consumption (26). $\mathrm{VO}_{2}$ measurements were made at all activity levels during the three balance periods. From the 
known oxygen cost of each activity level above the resting expenditure, and the estimate of the proportion of the day spent in these activities, we reached an assessment of the energy cost of activity in each infant.

During balance periods 1 and 2 , the majority of the infants were tube fed, so no allowance had to be made for the physical effort of feeding. The energy cost of bottle feeding, where applicable, was included in the measurements of pre- and postprandial metabolism.

We were unable to measure the energy cost of defecation which often looked considerable.

\section{CONSENT}

The consent of the mothers was obtained after explanations about the purpose of the studies.

\section{RESULTS}

\section{ENERGY RETENTION}

Mean energy intake during the studies was $757 \mathrm{~kJ} / \mathrm{kg}$. This did not vary significantly during the three balance periods because intake was as far as possible standardized at $200-230 \mathrm{ml}$ milk per $\mathrm{kg}$ body wt daily. Energy retention was very variable, ranging from 52-94\% in infants in apparent good health. This was, in part, due to day-to-day variation in the same infant, which could be as high as $30 \%$, and partly due to differences between infants. Acidosis impaired energy retention, as already described (4), and it fell as low as $32 \%$ in one infant with moderate acidemia who was otherwise well and active. Figure 1 shows the distribution of the proportion of energy retained, in bands of $10 \%$, during the entire period of the studies, the hatched areas indicating balances on acidemic infants.

Mean energy retention during the first balance period was 76.2 $\%$ (SD 8.3) or $592 \mathrm{~kJ} / \mathrm{kg}$ day (SD 8.1). During the second balance it increased to $79.5 \%$ (SD 7.6), $620 \mathrm{~kJ} / \mathrm{kg}$ day, but this increase was not significant using the paired $t$ test. In the three infants in whom a third balance was done, there was a further increase in energy retention, to $87.8 \%$.

\section{MEASURED ENERGY EXPENDITURE}

1) Resting Metabolic Rate. Minimum oxygen consumption during sleep in the hour preceding a feed increased with advancing maturity (Table 2). Mean minimum $\mathrm{VO}_{2}$ during the first balance period was $6.5 \mathrm{ml} / \mathrm{kg} \cdot \min (\mathrm{SD} 0.7$ ), increasing to $6.9 \mathrm{ml} / \mathrm{kg} \cdot \mathrm{min}$ (SD 0.9) in the second period, and to $7.1 \mathrm{ml} / \mathrm{kg} \cdot \min ($ SD 0.9) in the third period. The increase was significant when the individual measurements were compared by the paired $t$ test in the nine infants common to periods 1 and 2 . The corresponding metabolic rates were 192, 209, and $219 \mathrm{~kJ} / \mathrm{kg}$. day, respectively. Overall means for resting metabolic rates were about $15 \%$ higher than the minimum values, and were taken as the "resting metabolism" in calculating energy balance. The mean value during all the studies was $244 \mathrm{~kJ} / \mathrm{kg}$.day $(58.1 \mathrm{kcal})$.

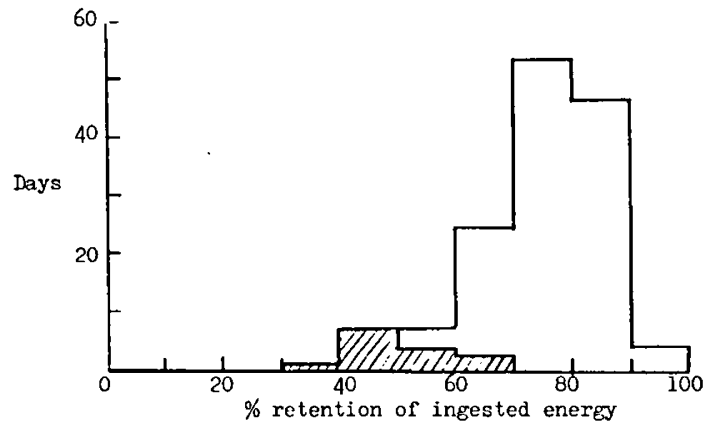

Fig. 1. Histogram showing distribution of energy retention as percentage of intake during the study periods (hatched area indicates collections made on acidemic infants).
Table 2. Minimum resting $\dot{\mathrm{V}} \mathrm{O}_{2}(\mathrm{ml} / \mathrm{kg} \cdot \mathrm{min})$ and $M R(\mathrm{~kJ} / \mathrm{kg}$. day), 3-4 hr after last feed

\begin{tabular}{|c|c|c|c|c|c|c|}
\hline & \multicolumn{2}{|c|}{$\begin{array}{l}\text { Balance } \\
\text { period } 1\end{array}$} & \multicolumn{2}{|c|}{$\begin{array}{l}\text { Balance } \\
\text { period } 2\end{array}$} & \multicolumn{2}{|c|}{$\begin{array}{l}\text { Balance } \\
\text { period }\end{array}$} \\
\hline & $\dot{\mathrm{V}} \mathrm{O}_{2}$ & MR & $\dot{\mathrm{VO}}_{2}$ & MR & $\dot{\mathrm{VO}}_{2}$ & MR \\
\hline 1. G. A. & 5.4 & 158 & 7.4 & 235 & 8.0 & 235 \\
\hline 2. H. S. & 5.5 & 161 & 6.2 & 177 & 6.3 & 218 \\
\hline 3. P. R. & 5.8 & 171 & 6.1 & 182 & 7.1 & 206 \\
\hline 4. P. H. & 6.6 & 211 & 7.6 & 225 & & \\
\hline 5. J. A. & 7.5 & 223 & 8.7 & 248 & & \\
\hline 6. T. F. & 7.0 & 208 & 7.1 & 209 & & \\
\hline 7. J. S. & 6.0 & 181 & 6.0 & 192 & & \\
\hline 8. Y. K. & 5.5 & 168 & 6.1 & 185 & & \\
\hline 9. S. I. & 6.1 & 177 & 6.8 & 227 & & \\
\hline 10. R. W. & 7.0 & 208 & & & & \\
\hline 11. S. B. & 6.7 & 201 & & & & \\
\hline 12. P. H. & 7.1 & 209 & & & & \\
\hline 13. G. B. & 7.7 & 226 & & & & \\
\hline 14. A. W. & 6.4 & 182 & & & & \\
\hline 15. M. M. & 6.9 & 200 & & & & \\
\hline Mean & 6.5 & 192 & 6.9 & 209 & 7.1 & 219 \\
\hline SD & 0.7 & 22 & 0.9 & 26 & 0.8 & 15 \\
\hline
\end{tabular}

2) Postprandial Metabolism. The mean increase in metabolic rate in the first hour after a feed was $17.1 \%$ in 92 studies done throughout the balance periods, determined by measuring the area under the curve. At $1 \mathrm{hr}, \mathrm{MR}$ remained considerably above resting values $(+17.5 \%)$. These results are shown in Figure 2 . There was a positive relationship between the magnitude of the increase in postprandial metabolism and the rate of weight gain. These data are to be published separately (1).

3) Energy Cost of Activity. Periods of activity associated with crying were invariably those of highest energy expenditure. Mean $\dot{\mathrm{VO}}_{2}$ results during the different activity levels in the three balance periods are shown in Table 3 . Infants who were in activity level 2 had increases in $\mathrm{VO}_{2}$ of about $25 \%$ above sleep levels. Mean increase in levels $3-4$ was $103 \%$, and in level $5,137 \%$. There was a tendency for the energy cost of these activities to increase during the three balance periods. From nursing observations, the infants spent about $55 \%$ of the time in sleep, $28 \%$ in activity level 2,15 $\%$ in levels $3-4$, and $2 \%$ in level 5 during the first balance period. In the second balance period, they spent about $48 \%$ of the time in sleep, $33 \%$ in activity level $2,16 \%$ in levels $3-4$, and $3 \%$ in level 5 .

The increased energy expenditure due to activity amounted to $23 \%$ above resting levels during balance period 1 and $34 \%$ during balance period 2 .

\section{STORED ENERGY}

Table 4 shows the dietary energy retention during the balances, together with an estimate from our data of energy dissipation as resting metabolism, postprandial metabolism, and activity. The difference between dietary energy retention and energy dissipation represents the stored energy available for growth, which averaged $230 \mathrm{~kJ} / \mathrm{kg}$ during the balances.

\section{GROWTH RATES}

To ensure good estimates of growth, the measurements were made throughout the infant's stay in the Special Care Baby Unit and the daily increments were calculated by the method of least squares over minimum periods of 7 days when growth velocity was changing, or for longer periods when growth was linear.

1) Weight gain. Weight gain varied from $4.6-30.9 \mathrm{~g} / \mathrm{kg} \cdot$ day during the balance periods (mean 13.7, SD 8.5). Mean weight gain during balance period 1 was $9.5 \mathrm{~g} / \mathrm{kg}$. day and during balance period 2, it was $17.6 \mathrm{~g} / \mathrm{kg} \cdot$ day. Individual weight gains are shown in Table 4. 
2) Other measurements. Mean daily increments in head circumference, linear measurements, and skinfold measurements during the balances are shown in Table 5 with their standard deviations. These measurements, which were all made weekly or twice weekly, showed essentially linear increases during the period of the infant's stay in hospital from the onset of the first balance until discharge. There was no significant difference in the mean rate of increase during the various balance periods, so they are not given separately in the table.

\section{RELATIONSHIP BETWEEN GROWTH AND ENERGY RETENTION}

Figure 3 shows the relationship between weight gain and energy retention during all the study periods. The relationship is positive and highly significant $(r=0.86, t=7.2, P<0.001)$, such that each

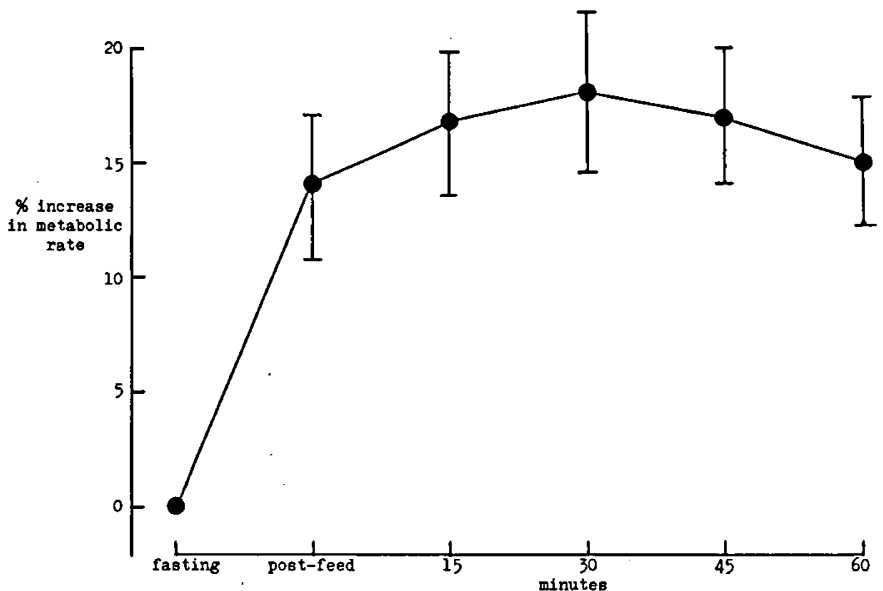

Fig. 2. Percentage increase in metabolic rate after feeds (bars indicate \pm ( SD)

Table 3. Mean oxygen consumption during different levels of activity in the three balance periods $(\mathrm{ml} / \mathrm{kg} \cdot \mathrm{min}) \pm 1 S D$

\begin{tabular}{lrrr}
\hline & $\begin{array}{c}\text { Balance } \\
\text { period 1 }\end{array}$ & $\begin{array}{c}\text { Balance } \\
\text { period 2 }\end{array}$ & $\begin{array}{c}\text { Balance } \\
\text { period 3 }\end{array}$ \\
\hline Sleeping (level 1) & $6.5 \pm 0.7$ & $6.9 \pm 0.9$ & $7.1 \pm 0.9$ \\
Awake, quiet (level 2) & $7.6 \pm 0.9$ & $8.5 \pm 1.2$ & $9.4 \pm 1.3$ \\
Awake, active (levels 3, 4) & $12.4 \pm 4.5$ & $14.1 \pm 3.9$ & $15.0 \pm 4.2$ \\
Crying (level 5) & $14.4 \pm 5.5$ & $16.8 \pm 5.8$ & $17.2 \pm 4.2$ \\
\hline
\end{tabular}

Table 5. Mean daily increment in head circumference, linear measurements and skinfold thickness measurements during the study period ( \pm I SD)

\begin{tabular}{ll}
\hline Head circumference $(\mathrm{cm})$ & $0.110 \pm 0.033$ \\
Crown-heel length $(\mathrm{cm})$ & $0.083 \pm 0.028$ \\
Forearm length $(\mathrm{cm})$ & $0.019 \pm 0.004$ \\
Knee-heel length $(\mathrm{cm})$ & $0.028 \pm 0.017$ \\
Triceps skinfold $(\mathrm{mm})$ & $0.080 \pm 0.037$ \\
Subscapular skinfold $(\mathrm{mm})$ & $0.069 \pm 0.029$ \\
\hline
\end{tabular}

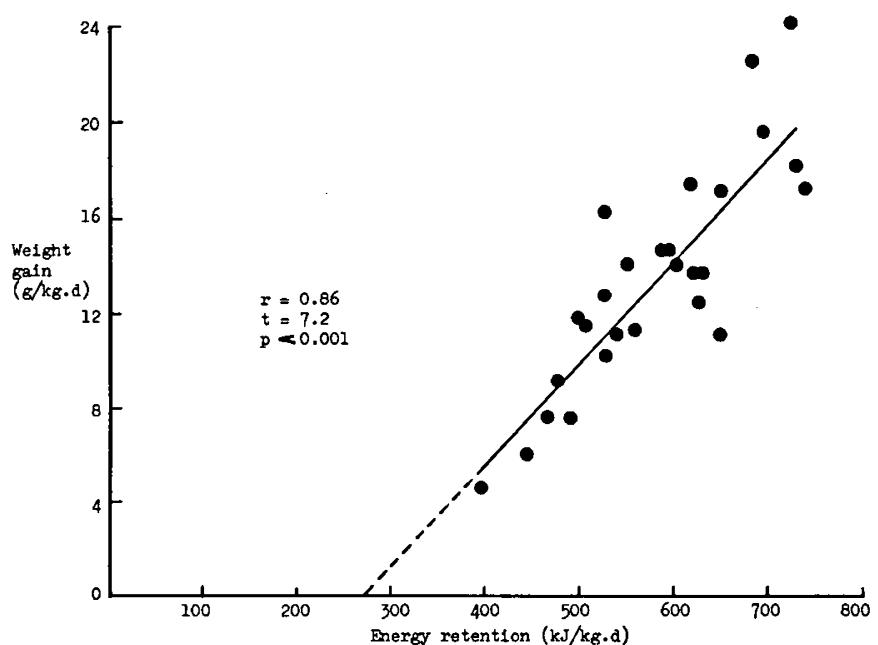

Fig. 3. Relationship between energy retention and weight gain during the study periods.

Table 6. Correlation between energy retention and head growth, linear growth, and subcutaneous fat accumulation (mean results from all balance periods)

\begin{tabular}{lccc}
\hline & $r$ & $t$ & $P$ \\
\hline $\begin{array}{l}\text { Energy retention } v s \text {. circumferential } \\
\quad \text { head growth }\end{array}$ & +0.34 & 1.3 & $>0.05$ \\
Energy retention $v$ s. crown-heel length & +0.29 & 1.1 & $>0.05$ \\
Energy retention $v$ s. forearm growth & +0.33 & 1.3 & $>0.05$ \\
Energy retention $v s$. lower leg growth & +0.39 & 1.5 & $>0.05$ \\
$\quad \begin{array}{l}\text { Energy retention } v \text { s. summed limb length } \\
\quad \text { measurements }\end{array}$ & +0.41 & 1.6 & $>0.05$ \\
$\quad \begin{array}{lll}\text { Energy retention } v s \text {. summed triceps and } \\
\quad \text { subcapular skinfolds }\end{array}$ & +0.55 & 2.3 & $<0.05$ \\
\hline
\end{tabular}

Table 4. Daily energy retention, weight gain, and energy expenditure as resting metabolism, postprandial metabolism, and activity (combined means of balance periods 1,2 , and 3 ).

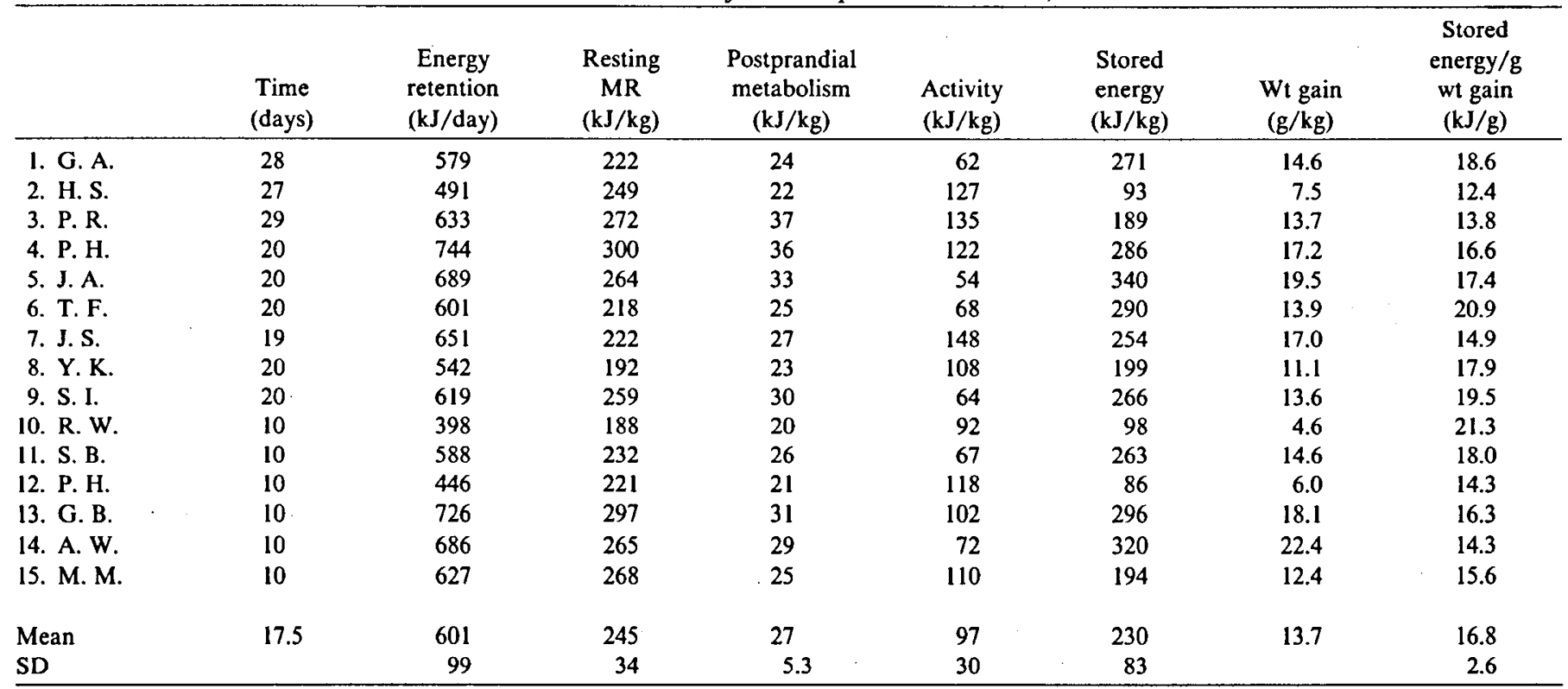




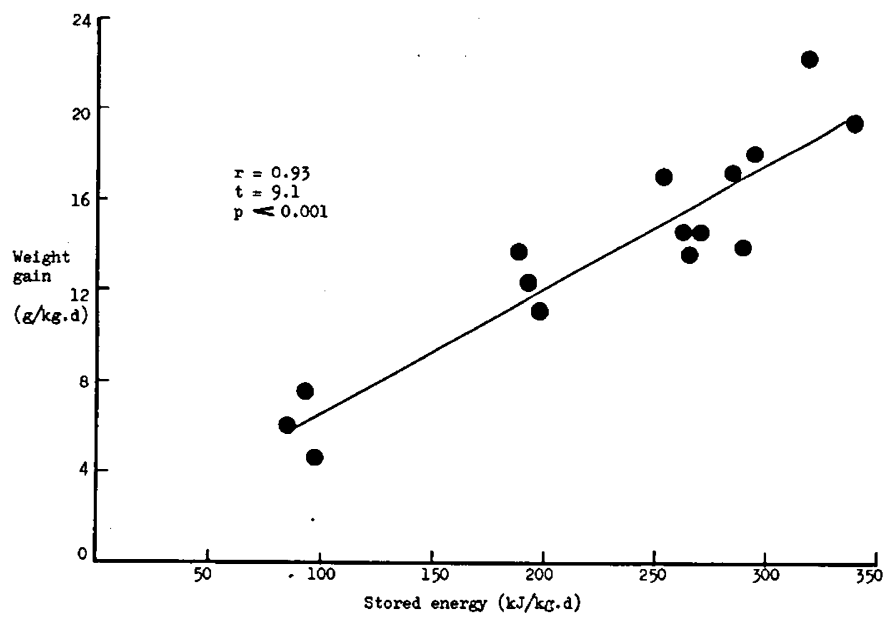

Fig. 4. Relationship between stored energy and weight gain during the study periods.

gram of weight gain was associated with the retention of $24 \mathrm{~kJ}$ of energy. Table 6 shows the correlations between energy retention and the measured parameters of growth, which were all positive, but did not reach statistical significance, except for weight and summed skinfold measurements.

Figure 4 shows the relationship between weight gain and stored energy. From the slope of the regression line, each gram of weight gain was associated with the storage of $16.8 \mathrm{~kJ}$ of energy.

\section{DISCUSSION}

\section{ENERGY RETENTION}

The majority of low birth weight infants in this country are fed, either partly or wholly, on one of the modern low-solute cow's milk preparations. The quoted energy content of these and other milks, is based on theoretical values for energy retention (32) which have not been verified in immature infants. Mean energy retention during 263 infant-days in our studies was $79 \%$ of the gross energy intake, but was very variable, as shown in Figure 1. This was not due to erratic defecation, because it was rare for infants to pass less than 4-5 stools/24-hr period. We think it is more likely to reflect variation in gut transit time, which could be as great as $100 \%$ judging by the time of appearance of the carmine markers. The increase in postprandial metabolism was also variable (4-38\%) and changed with the rate of weight gain. For these reasons there seems a strong case to be made for quoting the gross energy content of the milk, rather than a figure for "retention" derived from studies in different age groups. If, however, a value for milk energy were to be derived to take into account malabsorption of energy and urinary losses of nitrogenous compounds, then, disregarding postprandial metabolism, it would, in our infants, have been nearer $290 \mathrm{~kJ} / 100 \mathrm{ml}$ than the $260 \mathrm{~kJ}$ quoted.

Our values for energy retention are similar to those of Valman et al. (30) whose mean figure using another modern infant formula (SMA S26) was $82 \%$. Thus, there is considerable wastage of dietary energy in immature infants, although in our studies, energy retention increased with postnatal age, probably because of improved fat absorption (29). Even so, there was a wide daily variation in excretory energy losses, making it impossible to predict energy intake from feed volume with any precision. The classic studies of Gordon et al. (10) on energy absorption from a cow's milk formula of the 1940's suggested similar mean energy retention values, so our modern formula may not have progressed much in the intervening 37 years in the search for improved energy retention. We do not have sufficient data on other modern milks to know whether this particular brand falls below the general standard.

\section{ENERGY EXPENDITURE}

It is difficult to define basal metabolism in immature infants. They cannot be left unfed for long enough for measurements comparable to those done in adults to be obtained, and because they are, or should be, growing rapidly, their resting metabolism is never likely to be truly basal. Minimum sleeping values of $\mathrm{VO}_{2}$ and MR after a $3 \mathrm{hr}$ fast are as much as one can normally hope for as a measure of resting metabolic rate, and ours (Table 2) are similar to others in the literature $(9,17-19,21,23,24)$. There was a considerable variation in resting metabolic rate, and minimum levels underestimate the energy spent during sleep and apparent inactivity. The mean of all the measurements taken in our defined activity level 1 was about $15 \%$ higher than the minimum levels, and probably represents a more realistic value for resting metabolism. We have confirmed that resting MR increases with advancing maturity $(17,18)$. Accounting for one third of the retained food energy, resting metabolism is of great importance in energy balance.

It was not possible in our studies to measure directly the maintenance energy requirement (MER) (energy used by basal metabolism, postprandial metabolism, and minimal voluntary muscular activity, but not including requirements for growth or stress), because all infants were growing at the time of the measurements. MER can be determined indirectly from the regression analysis of energy retention against weight gain (being the intercept at zero weight gain, Fig. 3) and was $270 \mathrm{~kJ} / \mathrm{kg}$, or $1.2 \times$ the resting MR. This is rather less than the usually quoted value of $1.5 \times$ the BMR (35), but because resting metabolism in preterm infants is not basal, the difference is not surprising.

Postprandial metabolism is a neglected aspect of energy expenditure in low birth weight infants, although Mestyán (18) has published valuable data on it. Large increases in energy expenditure after meals are known to occur during rapid growth in older infants $(2,5,15)$, and it is apparent from Mestyán's data and from our own that this phenomenon also occurs in immature babies, whose growth rates are similar to those of infants recovering from malnutrition. In some postprandial and apparently resting infants, heat production may be as much as $40-50 \%$ above fasting levels, and it is tempting to link this with synthetic processes. In our studies the infants received on average about seven feeds/day and mean MR increased by about $17 \%$ in the hour after each feed. Allowing for the decline in MR in the succeeding period before the next feed, the sum effect of "specific dynamic action" was the expenditure of energy equivalent to more than $10 \%$ of the daily resting metabolism.

Energy expended in activity appears to be relatively small compared with later infancy, though here the difficulties of method are greatest. Relatively short-term observations of infant activity, linked with $\mathrm{V}_{2}$ measurements and extrapolated over a number of days can never be entirely satisfactory. Others have used this technique $(10,23)$ and, in general, our results are comparable to theirs. At most it can be said that the energy expended in muscular activity in immature infants is relatively small in comparison with their resting and postprandial metabolism, mainly due to the large proportion of the day spent in sleep. Infants became more active as they matured, so this aspect of energy balance assumes greater importance with the passage of time.

Energy Cost of Growth. Part of the energy used in growing is the stored energy of newly synthesized fat and protein. There is an additional cost, due to the energy used in tissue synthesis. The amount of energy used in this way is controversial $(1,25)$, but will be incorporated in the measurements of resting and postprandial heat production, and there is evidence that postprandial energy expenditure reflects synthetic processes $(5,8)$. The total energy cost of weight gain may be calculated by regression analysis of weight gain against energy retention, if weight gain is rapid enough. This can be derived from our data (Fig. 3) and amounts to $24 \mathrm{~kJ} / \mathrm{g}$ of new tissue deposited. This figure is close to other published results, predominantly from children with malnutrition $(3,13,22,25,31)$, for example, the data of Ashworth et al. (3) give 
a figure of $23.0 \mathrm{~kJ} / \mathrm{g}$ for infants recovering from malnutrition, and the mean value in the studies cited is about $22 \mathrm{~kJ} / \mathrm{g}$.

The energy stored in new tissue can also be derived from our data (Table 4 and Fig. 4 ) being the total energy retained minus the energy used in resting metabolism, postprandial metabolism, and activity. Mean stored energy during all the balance periods was $230 \mathrm{~kJ} / \mathrm{kg}$, or $16.8 \mathrm{~kJ} / \mathrm{g} \cdot \mathrm{kg}$ weight gain. The difference between the total energy cost of weight gain $(24 \mathrm{~kJ} / \mathrm{g})$ and the energy cost of tissue storage $(16.8 \mathrm{~kJ} / \mathrm{g})$ represents an additional oxidative cost of synthetic processes of $7.2 \mathrm{~kJ} / \mathrm{g}$, rather more than the figure of $4.6 \mathrm{~kJ} / \mathrm{g}$ derived by Spady et al. (25) for recovering malnourished children. The close agreement between the energy cost of catch-up growth in malnutrition and of normal growth in immature infants is of interest, because the efficiency of energy utilization is apparently quite different. It is possible that some of the difference may be accounted for by unrecognized thermal stress in the immature infants, because we were unable to measure energy expenditure continuously.

\section{CONCLUSION}

The energy cost of growth in immature infants, who have incomplete and variable energy absorption and high rates of nitrogen retention, can only be obtained accurately from balances over relatively long periods. By doing these, we have shown that the energy cost of weight gain is similar to that of recovering malnourished children, who are growing at similar rates.

There is a need to reconsider the factors used in calculating metabolizable energy in milk, because they are not applicable to immature infants and give an unrealistic picture of energy intake.

\section{REFERENCES AND NOTES}

1. Alvear, J., and Brooke, O. G.: Specific dynamic action in infants of low birth weight. J. Physiol., 275: 54P (1977).

2. Ashworth, A.: Metabolic rates during recovery from protein-calorie malnutrition: the need for a new concept of specific dynamic action. Nature, 223: 407 (1969).

3. Ashworth, A., Bell, R., James, W.P. T., and Waterlow, J. C.: Calorie requirements of children recovering from protein-calorie malnutrition. Lancet, 2: 600 (1968).

4. Brooke, O. G.: Influence of acidosis on energy absorption in immature infants. Arch. Dis. Child., 52: 809 (1977).

5. Brooke, O. G., and Ashworth, A.: Influence of malnutrition on the postprandial metabolic rate and respiratory quotient. Br. J. Nutr., 27: 407 (1972).

6. Donhoffer, S., Szegvari, G., Varga-Nagy, T., and Járai, T.: Über die Periodizitat der Chemischen Wärmeregulation der Ratte. Arch. Gesomte Physiol. Mens. Tiere (Pflügers) 265: 97 (1957).

7. Dubowitz, L. M. S., Dubowitz, V., and Goldberg, C.: Clinical assessment of gestational age in the newborn infant. J. Pediatr., 77: 1 (1970).

8. Garrow, J. S., and Hawes, S. F.: Role of aminoacid oxidation in causing "Specific Dynamic Action" in man. Br. J. Nutr., 27: 211 (1972).

9. Gentz, J., Kellum, M., and Persson, B.: Effect of feeding on oxygen consumption, R. Q. and plasma levels of glucose, FFA and D- $\beta$-hydroxybutyrate in newborn infants of diabetic mothers and small for gestational age infants. Acta Paediatr. Scand., 65: 445 (1976).

10. Gordon, H. H., Levine, S. Z., Deamer, W. C., and McNamara, H.: Respiratory Metabolism in infancy and childhood. XXIII Daily Energy requirements of premature infants. Am. J. Dis. Child., 59: 1185 (1940).

11. Hey, E. N.: The care of babies in incubators. In: D. Gairdner and D. Hull: Recent Advances in Paediatrics, 4th edition, p. 171 (Churchill, London, 1971).

12. Hommes, F. A., Drost, Y. M., Geraets, W. X. M., and Reijenga, M. A. A.: The energy requirement for growth: an application of Atkinson's metabolic price system. Pediatr. Res., 9: 51 (1975).

13. Kerr, D. S., Ashworth, A., Picou, D., Poulter, N., Seakins, A., Spady, D. W., and Wheeler, E. F.: Accelerated recovery from infant malnutrition with high calorie feeding. In: L. Gardner and P. Amacher: Endocrine Aspects of Malnutrition (Kroc Foundation, Santa Ynez, California, 1973).

14. Kildeberg, P.: Disturbances of hydrogen ion balance occurring in premature infants. II: Late metabolic acidosis. Acta Paediatr. Scand., 53: 517 (1964).

15. Krieger, I., and Cher, Y. C.: Calorie requirements for weight gain in infants with growth failure due to maternal deprivation, undernutrition, and congenital heart disease. Pediatrics, 44: 647 (1969).

16. Levine, S. Z., and Wheatley, M. A.: Respiratory metabolism in infancy and childhood: XVII. The daily heat production of infants. Am. J. Dis. Child. 5I: 1300 (1936).

17. Mestyán, J., Fekete, M., Bata, G., and Járai, I.: The basal metabolic rate of premature infants. Biol. Neonate, 7: 11 (1964).

18. Mestyán, J., Járai, I., Fekete, M., and Soltész, G.: Specific dynamic action in premature infants kept at and below the neutral temperature. Pediatr. Res., 3: 41 (1969).

19. Mestyán, G., Varga, F., Fohl, E., and Heim, T.: Oxygen consumption of hyperand hypothermic premature infants. Arch. Dis. Child., 37: 466 (1962).

20. Miller, D. S., and Payne, P. R.: A ballistic bomb calorimeter. Br. J. Nutr., 13: 501 (1965).

21. Okken, A., Jonxis, J. H. P., Rispens, P., and Zylstra, W. G.: New standards for "basal" heat production and evaporative and nonevaporative heat loss in low birth weight newborn infants. Pediatr. Res., 11: 539 (1977).

22. Payne, P. R., and Waterlow, J. C.: Relative energy requirements for maintenance, growth and physical activity. Lancet, 2: 210 (1971).

23. Rubecz, I., and Mestyán, J.: Activity, energy metabolism and post-natal age relationship in low-birth weight infants. Acta Paediatr. Acad. Sci. Hung., I6: 351 (1975).

24. Sinclair, J. C., Scopes, J. W., and Silverman, W. A.: Metabolic reference standards for the neonate. Pediatrics, 39: 724 (1967).

25. Spady, D. W., Payne, P. R., Picou, D., and Waterlow, J. C.: Energy balance during recovery from malnutrition. Am. J. Clin. Nutr., 29: 1073 (1976).

26. Stabell, V., Junge, M., and Fenner, A.: Metabolic rate and $\mathrm{O}_{2}$ consumption in newborns during different states of vigilance. Biol. Neonate, 31: 27 (1977).

27. Tanner, J. M., and Whitehouse, R. H.: Revised standards for triceps and subscapular skinfolds in British children. Arch. Dis. Child., 50: 142 (1975).

28. Tanner, J. M., Whitehouse, R. H., and Takaishi, M.: Standards from birth to maturity for height, weight, height velocity and weight velocity. Arch. Dis. Child., $41: 454$ (1966).

29. Tidwell, H. C., Holt, L. E., Farrow, H. L., and Neale, S.: Studies in fat metabolism, II. Fat absorption in premature infants and twins. J. Pediatr., 6: 481 (1935).

30. Valman, H. B., Aikens, R., David-Reed, Z., and Garrow, J. S.: Retention of nitrogen, fat and calories in infants of low birth weight on conventional and high volume feeds. Br. Med. J., 3: 319 (1974).

31. Waterlow, J. C.: The rate of recovery of malnourished infants in relation to the protein and calorie levels of the diet. J. Trop. Pediatr. Afr. Child Health, 7: 16 (1961).

32. Widdowson, E. M.: Calculation of calorific value of foods and diets. In: R. A. McCance and E. M. Widdowson: The Composition of Foods. Medical Research Council Special Report Series No. 297. (Her Majesty's Stationery Office, London, 1960).

33. Widdowson, E. M.: Changes in body proportions and composition during growth. In: J. A. Davis and J. Dobbing: Scientific Foundations of Paediatrics (Heinemann, London, 1974).

34. Widdowson, E. M.: Growth and composition of the fetus and newborn. In: N. S. Assali: Biology of Gestation (Academic Press, New York, 1968).

35. World Health Organization: Energy and protein requirements: report of a joint FAO/WHO ad-hoc Expert Committee (World Health Organization Technical Report Series No. 522, 1973).

36. The authors thank Professor J. C. Waterlow for his advice on the preparation of the manuscript.

37. Dr. Alvear was supported by a grant from the British Council.

38. Requests for reprints should be addressed to Dr. O. G. Brooke, Department of Child Health, St. George's Hospital, Blackshaw Road, London, S.W.17.

39. Received for publication November $28,1977$.

40. Accepted for publication May 3, 1978. 